\title{
DAMPAK GAYA KEPEMIMPINAN TRANSFORMASIONAL TERHADAP KEPUASAN KERJA PADA ASN MILENIAL DI KEMENTERIAN PERDAGANGAN
}

\author{
Agus Setiyo Utomo', Andrika Pesparani Nikerija Nainggolan² \\ 1,2Biro Organisasi dan Kepegawaian Kementerian Perdagangan \\ Article history \\ Received: 5 August 2020 \\ Revised : 12 August 2020 \\ Accepted : 19 August 2020 \\ *Corresponding author \\ Andrika Pesparani Nikerija Nainggolan \\ Email : andrikanainggolan@gmail.com
}

\begin{abstract}
Abstrak
Penelitian ini bertujuan mengidentifikasi dampak antara kepemimpinan transformasional dan kepuasan kerja PNS Generasi Milenial, Populasi penelitian terdiri dari PNS Generasi Milinneal terdaftar yang berlokasi di Kementerian Perdagangan Jakarta. Ada 59 survei dikirimkan ke PNS Generasi Milenial terdaftar. Mengenai kepemimpinan transformasional, survei diadaptasi dari Kuisioner Kepemimpinan Multifaktor (MLQ). Kepuasan Minnesota Angket (MSQ) yang dikembangkan oleh Weiss (1967) diadaptasi untuk mengukur faktor kepuasan kerja. Penelitian ini menunjukkan adanya hubungan yang positif dan signifikan secara statistik antara empat dimensi kepemimpinan transformasional dan dua puluh dimensi kepuasan kerja.

Keywords : kepemimpinan transformasional, Kepuasan Kerja, PNS Generasi Millineal, Kementerian Perdagangan

Abstract

The study has aimed at identifying the impact between transformational leadership and job satisfaction of Milenial Generation civil servant, the population of the study consisted of registered Milinneal Generation civil servant located in Ministry of Trade. There have been 59 surveys mailed out to registered Milenial Generation civil servant. 59 surveys have been returned with an $100 \%$ response rate. Regarding transformational leadership, the survey was adapted from the Multifactor Leadership Questionnaire (MLQ). The Minnesota Satisfaction Questionnaire (MSQ) developed by Weiss (1967) was adapted to measure job satisfaction. The present study has shown a statistically there is no relationship existing between the four dimensions of transformational leadership and the twentieth dimensions of job satisfaction. This study shows a positive and statistically significant relationship between the four dimensions of transformational leadership and twenty dimensions of job satisfaction.

Keywords: Transformational leadership, job satisfaction, Millinneal Generation civil servant, Ministry of Trade.
\end{abstract}

(C) 2020 Pusdiklat Perdagangan. All rights reserved 


\section{PENDAHULUAN}

Hari-hari ini semakin bertukar pengaturan organisasi dan lingkungan yang telah membuat sulit bagi pengambil keputusan untuk mengikuti gaya pengawasan tertentu yang tidak hanya mengkoordinasikan jaringan produksi yang kompleks tetapi juga memadukan kerja sama pasar (Jing \& Avery, 2016). Juga ditemukan bahwa pendorong perilaku manusia lebih penting untuk memahami kepemimpinan di berbagai negara dan budaya (Arvey, Dhanaraj, Javidan, \& Zhang, 2015). Adaptasi gaya kepemimpinan yang tepat tergantung pada konteks budaya, yang bervariasi dari satu benua ke benua lain (Jing \& Avery, 2016). Di Asia, arena kritis subur tersedia karena nilainilai sosial secara signifikan dipengaruhi oleh hasil kepemimpinan (Arvey et al., 2015).

Oleh karena itu untuk mencapai hasil yang ditargetkan untuk organisasi, harus ada hubungan pemimpin pengikut (Bass, 1990; Saleem, 2015).

Baru-baru ini, dalam siklus bisnis yang dinamis dan lingkungan yang kompetitif, organisasi telah mulai mencari peluang baru untuk mencapai keunggulan kompetitif untuk menjaga keberlanjutan di pasar dunia. Kepuasan kerja telah menjadi komponen kunci dari organisasi yang sukses (Abuhashesh, et al., 2019). Kepuasan kerja telah dipelajari secara luas dalam literatur sebelumnya dan beberapa spesialis, manajer, dan peneliti percaya bahwa itu memainkan peran penting dalam produktivitas dan tingkat retensi karyawan. Kepuasan kerja dapat dipengaruhi oleh banyak faktor, seperti promosi, upah, tunjangan, kondisi kerja, kepemimpinan, hubungan sosial, dan pekerjaan itu sendiri (Parvin \& Kabir, 2011). Saat ini, organisasi harus berubah secara konstan karena pengembangan dan pertumbuhan terjadi melalui perubahan (Karajeh \& Maqableh, 2014; Maqableh, et al., 2015; Petrou, et al., 2018).

Selama bertahun-tahun, salah satu atribut utama yang berkontribusi pada sikap dan perilaku karyawan yang diselidiki oleh ilmuwan sosial adalah gaya kepemimpinan (Chen, Zhou, \& Klyver, 2019; Kaya, Aydin, \& Ongun, 2016; Saher, Naz, Tasleem, Naz, \& Kausar, 2013; Saleem, 2015; Wang, Law,
Hackett, Wang, \& Chen, 2005; Warrick, 1981). Pemimpin yang efektif adalah kebutuhan organisasi saat ini. Gaya kepemimpinan tradisional menghadapi ancaman kelangsungan hidup, karena perubahan dramatis dalam peran dan tanggung jawab pemimpin telah terlihat dalam keberhasilan organisasi saat ini (Saleem, 2015). Seorang pemimpin yang sempurna membantu bawahannya untuk bekerja dengan efisiensi dan efektivitas besar tanpa merasa tidak puas.

Tujuan utama dari perubahan organisasi adalah untuk meningkatkan misi dan visi untuk beradaptasi dengan perubahan global (Castillo et al., 2018). Organisasi berjuang untuk mengembangkan dan menerapkan berbagai jenis perubahan untuk merespons perkembangan pesat lingkungan eksternal (disebabkan oleh kekuatan teknologi, sosial, ekonomi, dan politik). Dengan demikian, organisasi harus bereaksi secara efektif terhadap tantangan-tantangan ini dan memanfaatkan peluang (Masa'deh, 2012; Masa'deh, et al., 2015; Heckelman, 2017). Perubahan organisasi juga terkait dengan harapan tinggi untuk meningkatkan kinerja (Schneider, et al., 1996). Perubahan datang dalam berbagai bentuk; sedangkan beberapa perubahan berdampak pada organisasi secara keseluruhan, yang lain hanya memengaruhi departemen, tim, atau proses tertentu (Yousef, 2017).

Milenial dilahirkan antara tahun 1980 dan 2001, meskipun beberapa sumber berpendapat mereka yang lahir pada pertengahan tahun 2000-an juga merupakan bagian dari generasi ini. Milenium sekarang melebihi jumlah Generasi Baby Boomer, dan akan terus tumbuh, dengan puncak populasi penuh mereka yang terjadi pada tahun 2036 dengan perkiraan 81,1 juta.

Terminologi "milenial" pertama kali digagas oleh dua orang ahli sejarah dari Amerika Serikat, William Strauss dan Neil Howe, dalam buku best seller-nya yang berjudul Millennials Rising: The Next Great Generation (2000). Istilah ini diciptakan pada tahun 1987, yakni pada saat anak-anak yang lahir pada tahun 1982 masuk pra-sekolah. Saat itu media mulai menyebut milenial sebagai kelompok yang terhubung ke milenium baru di saat mereka 
Iulus SMA di tahun 2000. Tidak ada konsensus mengenai rentang tahun lahir generasi milenial. Dalam Statistik Gender Tematik: Profil Generasi Milenial Indonesia yang diterbitkan tahun 2018, konsep generasi milenial Indonesia adalah Penduduk Indonesia yang lahir antara tahun 1980-2000.

Memahami generasi milenial sangat penting karena sejak tahun 2017, sebesar 33,75 persen jumlah keseluruhan penduduk Indonesia adalah generasi milenial. Bila dilihat jumlah penduduk usia produktif yang berusia antara 15-64 tahun, sekitar 50,36 persen adalah generasi milenial. Sebagai penduduk terbesar, tentunya generasi milenial akan berperan besar pada era bonus demografi, khususnya pada rentang tahun 2020-2030.

Jumlah penduduk milenial, bukan hanya penting bagi para pebisnis yang melihatnya sebagai pasar yang besar. Generasi milineal yang akan memegang kendali atas roda pembangunan khususnya di bidang perekonomian yang diharapkan akan mampu membawa bangsa Indonesia menuju ke arah pembangunan yang lebih maju dan dinamis. Sebagai modal besar pembangunan suatu bangsa, diharapkan generasi milenial memiliki potensi yang lebih unggul dibandingkan generasi-generasi sebelumnya. Oleh sebab itu, penting bagi pimpinan yang memiliki anggota kelompok atau bawahan para milenial untuk memahami karakteristik milenial agar dapat memengaruhi mereka menuju tujuan perusahaan atau tujuan bersama yang disepakati. Para junjungan istilah milenial untuk mereka yang dipandang sebagai pemimpin - tidak berarti selalu berasal dari generasi yang berusia lebih tua dibandingkan para milenial. Para milenial yang memiliki peran sebagai pemimpin kelompok, organisasi, atau perusahaan juga perlu memahami cara memimpin dengan efektif.

Pengguna internet tahun 2014 sebesar 83,6 juta, pertumbuhan penetrasi internet 33\%. Dari data badan statistik menunjukkan jumlah tenaga kerja di Indonesia lebih dari 50\% berumur dibawah 30 tahun. Sehingga dapat dikatakan generasi millennial menjadi pekerja aktif di dalam dunia kerja saat ini, yang melakukan akses terhadap teknologi dan informasi secara rutin dan berkesinambungan. Pada perubahan konsep industri konvensional menuju industri modern yang disebut industri 4.0, perusahaan di Indonesia dituntut untuk melakukan transformasi agar dapat bertahan ditengah derasnya arus persaingan. Disinilah pentingnya peran seorang pemimpin dalam merumuskan strategi bisnis dan memaksimalkan potensi yang dimiliki. Dewasa ini karakter kepemimpinan transformasional dipilih sebagai alternatif gaya kepemimpinan yang mencerminkan karakter millennial dan berorientasi pada peningkatan produktivitas melalui pendekatan kreativitas dan inovasi (Suyanto, 2018).

Generasi milenial memang selalu jadi sorotan. Yang positif, generasi ini antara lain dipandang kreatif, fasih dengan teknologi informasi (gawai), terbiasa multitasking, kritis karena kebanjiran informasi, peduli dengan isu-isu kemanusiaan dan lingkungan hidup. Sedangkan yang negatif, mereka adalah generasi yang manja, inginnya serba instan, tidak suka membuat rencana jangka panjang (tidak menabung untuk masa depan), kurang keterampilan sosial, dan kurang berani mengambil risiko.

Banyak sekali penelitian akademik yang mencoba mengidentikasikan sikap, perilaku, dan preferensi para milenial. Menurut penelitian tersebut, para milenial tumbuh dalam lanskap teknologi yang berkembang pesat sehingga menjadi pengguna intensif produk high-tech. Dibandingkan generasigenerasi sebelumnya, milenial lebih mengerti teknologi dan terbiasa melakukan bayak kegiatan sekaligus, atau multi-tasking. Mereka cenderung percaya pada aksi kolektif dan kerja tim. Juga, mereka memiliki kecenderungan untuk mempertanyakan aturan dan menantang norma-norma di tempat kerja.

Milenial adalah idealis, sangat optimis, dan percaya diri. Mereka memiliki harapan yang tinggi dan sangat bangga dengan diri mereka sendiri. Selain itu, mereka percaya bahwa mereka memberikan kontribusi besar untuk pekerjaan mereka dan pimpinan diharapkan untuk mengakui pekerjaan baik mereka. Mereka juga mengharapkan promosi dan pengembangan yang cepat. Oleh karena itu, pengakuan dan penghormatan 
penting bagi mereka. Anehnya, meskipun milenial memiliki tingkat kepercayaan diri yang tinggi, mereka lebih cenderung mencari arahan dan panutan dari sosok yang menjadi idola dan dihormati.

Dalam hal sentralitas kerja, milenial kurang mau mendedikasikan sebagian besar waktu mereka untuk bekerja. Kehidupan sosial sangat penting, dimana work-life balance atau keseimbangan antara kehidupan pribadi dan kerja memainkan peran kunci bagi mereka. Way of life atau cara menjalani kehidupan dinilai oleh milennial sebagai nilai kerja yang paling penting. Oleh karena itu jadwal kerja yang fleksibel dianggap sebagai batu loncatan menuju kesuksesan. Memiliki jadwal kerja yang fleksibel berarti bahwa pekerjaan itu tidak diukur oleh waktu yang mereka habiskan untuk itu. Yang paling penting adalah apakah pekerjaan itu selesai dan tujuan yang diperlukan tercapai.

Para milenial juga ditemukan lebih termotivasi oleh penghargaan ekstrinsik. Misalnya, imbalan upah/gaji, bonus, promosi, atau sekedar pujian. Milenial menganggap economic return atau imbalan yang akan diperoleh dari investasi pada waktu dan pekerjaan merupakan nilai-nilai kerja yang jauh lebih penting dibandingkan dengan generasi sebelumnya. Ketika memilih alternatif pekerjaan, tunjangan pensiun akan menjadi salah satu faktor penting untuk dipertimbangkan. Hal ini mungkin terkait dengan fakta bahwa milenial cerdas secara finansial.

Studi berbeda juga menemukan bahwa penghargaan finansial kurang penting daripada pekerjaan yang bermakna. Pekerjaan dianggap bermakna oleh milennial jika melayani orang lain, meningkatkan kehidupan, dan membawa kebahagiaan pribadi. Sementara itu, milennial memandang pekerjaan ideal sebagai posisi yang mencakup interaksi dengan orang lain dan lebih santai.

Survei yang dilakukan majalah Forbes di akhir tahun 2019 menunjukkan bahwa para milenial di Amerika Serikat sangat menyukai Elon Musk (sebelumnya Steve Jobs). Mereka ingin bekerja di bawah pimpinan Musk, seorang insinyur berusia 49 tahun, pendiri, dan pimpinan dari perusahaanperusahaan futuristic Tesla, Inc., SpaceX, Boring Company, dan lain-sebagainya.

Majalah yang sama juga memilih Musk, bersama Jeff Bezos pendiri amazon.com, sebagai pemimpin paling inovatif di Amerika tahun 2019. Para milenial menyukai Musk karena lima alasan: futuristik, realistis, good guy, selalu menjaga hubungan dengan penggemarnya melalui media sosial, dan punya rencana jelas untuk mengirim milenial ke bulan.

Terlepas dari hasil survei di Amerika Serikat tersebut, survei lain menunjukkan tujuh sifat kepemimpinan yang paling sering diidentifikasi oleh milenial: membuka komunikasi (97,9\%), menghargai orang $(85,4 \%)$, memiliki visi $(79,1 \%)$, mempunyai pengaruh positif $(75 \%)$, percaya diri $(68,7 \%)$, integritas $(64,5 \%)$, dan menghargai kerja tim (62,5\%).

Sifat-sifat manajerial yang paling memotivasi bagi milenial adalah lead by example atau memimpin dengan memberi contoh, pekerja keras, ramah, memotivasi, mendorong, dan memahami. Sebaliknya, milenial tidak menyukai pimpinan yang minim komunikasi, kasar, malas, berorientasi teknis, terlalu mengatur dan senang menghukum. Selain itu, milenial lebih suka pemimpin yang peduli tentang mereka dan dapat dipercaya. Studi tahun 1978 menunjukkan bahwa kepemimpinan transformasional menyarankan agar pemimpin menginspirasi pengikut melalui pencapaian tujuan kelompok atau organisasi. Versi terbaru dari teori ini memuat empat dimensi kepemimpinan transformasional yang lebih kekinian. Dimensi-dimensi itu adalah karisma atau pengaruh ideal, motivasi inspirasional, stimulasi intelektual, dan pertimbangan individual.

Studi mendalam mengenai milenial di Amerika Serikat dengan idolanya, Elon Musk, menunjukkan bahwa milenial menyukai Musk karena menguasai data dan informasi dengan baik, mampu membicarakan hal-hal yang kompleks dengan gamblang dan inspiratif. Dengan kata lain, pemimpin transformasional dicirikan sebagai sosok yang berperilaku dengan cara yang mengagumkan sehingga pengikut 
mengidentifikasi diri mereka dengan pemimpin, mengartikulasikan visi yang menginspirasi kepada pengikut, mendorong dan merangsang kreativitas pengikut, dan memenuhi kebutuhan masing-masing pengikut melalui kegiatan pendampingan atau pembinaan.

Pemimpin transformasional memiliki kemungkinan untuk disukai oleh karyawan milenial dengan cara mereka menantang pengikut dengan standar tinggi, mengkomunikasikan optimisme tentang pencapaian tujuan masa depan, dan mengumpulkan gagasan-gagasan pengikut. Pendekatan ini cocok dengan karakteristik milenial, yaitu optimisme dan kepercayaan diri yang tinggi. Dengan memberikan pertimbangan individual kepada pengikut, pemimpin transformasional lebih cenderung dihormati oleh milenial karena mereka lebih suka pendekatan kepemimpinan seperti mentor, yang memberikan komunikasi individual dan perhatian khusus.

Milenial juga lebih tertarik memiliki pemimpin yang menjadi model atau panutan. Pemimpin transformasional, yang perilakunya mengagumkan, akan menciptakan identifikasi pengikut-pemimpin, dapat menggunakan karakteristik ini untuk melibatkan karyawan milenial.

Namun demikian, para pimpinan yang menjadi panutanque bagi para milenial, perlu berhati-hati dengan karakter milenial yang cenderung individualis. Mendorong perilaku kolektif pada milenial yang individualis terbukti bukan tugas yang mudah. Majalah terkemuka TIME, pernah mengangkat topik milenial sebagai tajuk utama dengan judul: The Me Me Me Generation (TIME, 9 Mei 2013), dengan ulasan yang antara lain mengangkat karakteristik individualis milenial. Lebih jauh lagi, penurunan sentralitas kerja secara signifikan menurunkan minat pada visi yang diberikan oleh pemimpin dan, sebagai konsekuensinya, mengurangi kekuatan motivasi inspirasional dari pimpinan.

Pada beberapa tahun terakhir karyawan generasi milenial mulai mendapatkan sorotan dibidang industri dan organisasi. Hal ini dikarenakan jumlah karyawan generasi milenial yang semakin bertambah dari tahun ke tahun.

Perbedaan generasi menyebabkan perbedaan yang signifikan terhadap nilai, sikap, preferensi, dan perilaku dari generasi milenial (Hernaus \& Vokic, 2014). Oleh karenanya generasi milenial cenderung memiliki ciri seperti cerdas, kreatif, produktif, berorientasi pada pencapaian prestasi (achievement oriented), mencari pengembangan personal, kebermaknaan karir, dan mencari mentor atau supervisor untuk mendorong dan memfasilitasi pengembangan profesionalitas (Kicheva, 2017). Hannus (2016) menyatakan bahwa, para generasi milenial akan merasa termotivasi dalam bekerja apabila mereka mendapatkan feedback dan perhatian secara personal, adanya mentoring dan empowerment terhadap diri mereka, komunikasi yang transparan dan terbuka dengan atasan, goal setting dan visi yang jelas, adanya apresiasi terhadap kesejahteraan dan work-life balance, serta adanya motivasi ekstrinsik yang mendorong mereka untuk semakin termotivasi dalam bekerja. Tanner (2010) juga menyebutkan generasi milenial tidak mengharapkan untuk bekerja di bidang karir yang sama, generasi milenial juga mengharapkan perusahaan mampu menyediakan keseimbangan kehidupan kerja, kompensasi yang adil, pengembangan profesional, kesempatan untuk membuat perbedaan, kepemimpinan yang menginspirasi, dan lingkungan kerja yang positif.

Peneliti melaksanakan penelitian pendahuluan guna mengetahui pemahaman, persepsi, pendapat ASN Milineal mengenai harapan Gaya Kepemimpinan dan Kepuasan Kerja pada Organisasi Kementerian Perdagangan diantara lain yang dapat disimpulkan adalah

1. Kepemimpinan yang diharapkan adalah kepemimpinan yang demokratis dan transformasional.

2. Birokrasi yang cepat, efisien, efektif.

3. Teknologi yang mutakhir dan ahli dalam teknologi.

4. Pemberian reward dan apresiasi yang berimbang dengan pencapaian. 
5. Fleksibilitas dalam pekerjaan.

6. Lingkungan pekerjan yang dinamis, berpikir kritis, kreatif, inovatif, aktif dan terbuka, sikap yang lebih maju dan modern, berekspresif, beretika sopan santun dan normatif.

7. Visioner, berfokus pada pengembangan diri dan diklat kepemimpinan serta karir.

Pada Penelitian yang dilakukan oleh Baihaqi (2010) Menunukkan bahwa Gaya Kepemimpinan memiliki pengaruh positif dan signifikan terhadap kepuasan kerja. Gaya kepemimpinan dipandang secara langsung mempengaruhi kepuasan kerja melalui kecermatannya dalam menciptakan pekerjaan dan lingkungan kerja yang menarik, pelimpahan tanggung jawab serta penerapan peraturan dengan baik. Namun disisi lain, penelitian yang dilakukan oleh Siregar (2006) Gaya kepemimpinan tidak mempengaruhi kepuasan kerja karyawan. Penelitian ini berusaha untuk menemukan korelasi secara deskriptif terkait aktualisasi proses kepemimpinan transformasional terhadap kepuasan kerja di Kementerian Perdagangan sehingga dapat memberikan masukan secara ilmiah kepada stakeholder yang terkait pengembangan Sumber Daya Manusia.

\section{METODOLOGI}

\section{Metode pengolahan data}

Pendekatan metode yang akan digunakan pada mekanisme distribusi ini adalah deskriptif korelasional bertujuan membuat deskripsi secara sistematis, faktual, dan akurat mengenai fakta-fakta dan sifat-sifat dari populasi. Melalui penerapan metode deskriptif diharapkan peneliti mendapatkan informasi yang tepat dan akurat serta gambaran korelasi dari dampak gaya kepemimpinan $(X)$ terhadap kepuasan kerja (Y). Gay dalam Mahmud (2011, hlm. 159) berpendapat bahwa ukuran minimum sampel yang dapat diterima berdasarkan metode penelitian yang digunakan, yaitu metode deskriptif korelasional, minimal 30 subjek.

Perceptions of Leadership (angket). Kuesioner merupakan teknik pengumpulan data yang dilakukan dengancara memberi seperangkat pertanyaan atau pernyataan tertulis kepada responden untuk dijawabnya. (Sugiyono, 2017, p.199). Alasan memilih teknik ini adalah karena populasi penelitian tersebar di wilayah yang luas serta dengan jumlah responden yang cukup besar. Adapun jenis kuesioner yang dipilih adalah angket tertutup yaitu responden menjawab pernyataan dengan memilih alternatif jawaban yang telah tersedia.

Angket tertutup tersebut dikonversi menjadi sebuah nilai dengan Skala likert kemudian setelah data terkumpul keseluruhan lalu diolah menggunakan alat bantu sehingga menghasilkan kesimpulan dari penelitian yang dilakukan.

\section{HASIL DAN PEMBAHASAN}

Dalam penelitian ini menggunakan teknik analisis regresi berganda. Analisis variabel prediktor dan ditandai dengan huruf $X$, kedua variabel dependen: yaitu variabel yang nilainya tergantung pada variabel independent, sering disebut variable respon dan ditandai dengan $Y$.

Uji Korelasi digunakan untuk mengetahui besarnya pengaruh perubahan dari suatu variabel independent terhadap variabel dependent. Variabel independent yaitu variabel yang nilainya tidak tergantung pada variabel lain, dan sering disebut variabel prediktor dan dikombinasikan dengan huruf $X$, kedua variabel dependen : yaitu variabel yang nilainya tergantung pada variabel independent, sering disebut variable respon dan dikombinasikan dengan $Y$.

\section{Identifikasi Parameter penentu klaster}

Instrumen Kepemimpinan Transformasional (Multifactor Leadership Questionnaire-MLQ) :
a. Idealized influence/ kharismatik,
b. Inspirasioanal Motivation
c. Intellectual Stimulation
d. Individualized Consederation

a)Charisma atau idealized Influenced merupakan sebuah proses yang padanya seorang pemimpin mempengaruhi para pengikut dengan menimbulkan emosi-emosi yang kuat dan identifikasi dengan pemimpin tersebut. 


\begin{abstract}
b) Inspirational motivation merupakan sejauh mana seorang pemimpin mengkomunikasikan sebuah visi yang menarik, menggunakan simbol-simbol untuk memfokuskan usaha-usaha bawahan, dan memodelkan perilaku-perilaku yang sesuai.

c) Intellectual Stimulation adalah sebuah proses yang padanya para pemimpin meningkatkan kesadaran para pengikut terhadap masalah-masalah dan mempengaruhi para pengikut untuk memandang masalah-masalah dari sebuah perspektif baru.

d)Individualized consideration merupakan sebuah proses yang padanya seorang pemimpin memberi dukungan, membesarkan hati dan memberi pengalamanpengalamantentang pengembangan kepada para pengikut.
\end{abstract}

The Minnesota Satisfaction Questionaire dirancang untuk mengukur kepuasan dari seorang karyawan dengan pekerjaannya. MSQ mengukur kepuasan kerja di 20 indikator yang berbeda:

\section{Ability Utilization \\ Compensation \\ Achievement \\ Activity \\ Advancement \\ Authority \\ Companies Policy Security \\ Social Status Variety \\ Moral Values Responsibilities \\ Recognition \\ Supervision-Human Relations \\ Supervision-Technical \\ Working Conditions}

Dalam penyusunan instrumen penelitian digunakan model dari Rensis Likert. Menurut Sugiyono (2012, hlm. 134), Skala Likert digunakan untuk mengukur sikap, pendapat dan persepsi seseorang atau sekelompok orang tentang fenomena sosial. Dengan menggunakan Skala Likert, maka variabel yang akan diukur dijabarkan menjadi indikator dan sub indikator. Kemudian sub indikator tersebut dijadikan sebagai titik tolak untuk menyusun item-item instrumen berupa pernyataan yang perlu dijawab oleh responden. Adapun skala option dan pembobotan yang digunakan seperti pada tabel 1 .

Tabel 1 Pembobotan Option
Kepemimpinan Transformasional
Kepuasan Kerja
\begin{tabular}{|l|l|l|}
\hline No & Option & Skor \\
\hline 1 & Sangat Setuju & 5 \\
\hline 2 & Setuju & 4 \\
\hline 3 & Netral & 3 \\
\hline 4 & Tidak Setuju & 2 \\
\hline 5 & Sangat Tidak Setuju & 1 \\
\hline
\end{tabular}

\section{Klasterisasi untuk menentukan sentra distribusi.}

Semua data dimasukkan ke dalam dan dianalisis menggunakan Statistical Package for the Social Sciences (SPSS) for Windows, versi 23.0. Sebelum analisis statistik, perapihan data dilakukan dengan menggunakan Microsoft Excel 2016

Korelasi Pearson digunakan untuk menguji hubungan yang signifikan antara variabel kontinu dari empat subskala kepemimpinan transformasional MLQ-5X instrumen dan tingkat kepuasan kerja ASN Generasi Milenial. Sugiyono (2017, p.147) memberikan interpretasi koefisien korelasi seperti terdapat dalam Tabel 2.

Tabel 2 Interpretasi Koefisien Korelasi Sumber:Sugiyono (2017,p.147)

\begin{tabular}{|l|l|}
\hline $\begin{array}{l}\text { Interval } \\
\text { Koefisien }\end{array}$ & Tingkat Hubungan \\
\hline $0,00-0,199$ & Sangat Rendah \\
\hline $0,20-0,399$ & Rendah \\
\hline $0,40-0,599$ & Sedang \\
\hline $0,60-0,799$ & Kuat \\
\hline $0,80-1,000$ & Sangat Kuat \\
\hline
\end{tabular}

Pada tabel 3 menunjukkan bahwa Pearson Correlation Gaya Kepemimpinan terhadap Kepuasan Kerja sebesar 0,821 dan Signifikansi 0,000 . Hal ini menunjukan bahwa antara Gaya Kepemimpinan dengan Kepuasan Kerja dalam penelitian ini memiliki korelasi yang sangat kuat yaitu 0,821 dan memiliki korelasi signifikan $(0,000<0,05)$. 
Tabel 3 Hasil Uji Korelasi Pearson

$$
\text { correlations }
$$

\begin{tabular}{|ll|r|r|}
\hline & \multicolumn{1}{|c|}{$\begin{array}{c}\text { Gaya } \\
\text { Kepemimpin } \\
\text { an }\end{array}$} & $\begin{array}{c}\text { Kepuasan } \\
\text { Kerja }\end{array}$ \\
\hline Gaya Kepemimpinan & Pearson Correlation & 1 & $.821^{\prime \prime}$ \\
& Sig. (2-tailed) & 59 & .000 \\
& $\mathrm{~N}$ & $.821^{\prime \prime}$ & 59 \\
\hline Kepuasan Kerja & Pearson Correlation & .000 & 1 \\
& Sig. (2-tailed) & 59 & 59 \\
\hline & $\mathrm{N}$ &
\end{tabular}

Sumber: Data diolah, 2020

\section{KESIMPULAN}

\section{A. SIMPULAN}

Berdasarkan hasil uji korelasi antara gaya kepemimpinan dan kepuasan kerja dapat diketahui bahwa probabilitas 0,000 $<0.05$ (taraf signifikan 5\%) dan nilai korelasi sebesar 0,821 maka Ho diterima sehingga dapat disimpulkan bahwa ada hubungan antara gaya kepemimpinan dan kepuasan kerja yang positif dan signifikan. Temuan yang dapat disimpulkan dalam penelitian ini adalah:

1. Gaya kepemimpinan transformasional mendapatkan rata-rata 3,3 dengan nilai terendah pada variabel bahwa pimpinan tidak menghubungi responden apabila responden tidak menghubungi dia yaitu mendapat skor 2,6 yang berarti bahwa pimpinan senantiasa menghubungi responden dalam koordinasi pekerjaan baik dihubungi lebih dahulu atau tidak.

Kepuasan Kerja mendapatkan rata-rata skor 3,5 dengan nilai terendah ada pada 2 varibel yaitu variabel gaji yang diterima sebanding dengan jumlah pekerjaan yang dilakukan dan kondisi lingkungan kerja seperti ketersediaan ruangan dan peralatan kerja dari organisasi cukup memadai. Hal ini mengindikasikan bahwa responden rata-rata memberikan penilaian bahwa gaji serta fasilitas menjadi titik kunci yang perlu diperhatikan oleh pimpinan organisasi.

\section{B. Rekomendasi}

Saran untuk kebijakan instansi perlunya pengelolaan SDM ASN Generasi Millenial di Kementerian Perdagangan sebai berikut:
1. Gaya kepemiminan transformasional menekankan prinsip dan dukungan inspirasional untuk pengembangan sumber daya manusia yang berguna untuk memudahkan adaptasi terhadap perubahan akibat dari kemajuan teknologi informasi dalam industri 4.0.

2. Gaya kepemimpinan transformasional cocok untuk organisasi dengan lingkungan yang dinamis yang membutuhkan tingkat kreativitas dan inovasi yang tinggi.

3. Hasil yang diharapkan dari penerapan gaya kepemimpinan transformasional hanya dapat diraih disaat pemimpin terus memberikan inspirasi kepada bawahannya untuk lebih sadar akan pentingnya dari tujuan suatu pekerjaan/kegiatan, memberi perhatian khusus pada aktualisasi harga diri karyawan, memberikan makna dan tugas yang menantang bagi pengembangan pegawai, mendorong semangat dan kreativitas pegawai serta melakukan identifikasi perbedaan kebutuhan, kemampuan dan aspirasi ketika menyediakan pembinaan, pengembangan dan pengawasan.

Untuk melengkapi kepemimpinan transformasional, perlu dipertimbangan hasil studi yang memunculkan teori eLeadership. Teori ini mempelajari kepemimpinan dalam lingkungan kerja yang didukung teknologi, yang berdampak pada potensi interaksi, jarak ruang fisik, dan jaringan komunikasi elektronik. Pendekatan teori eLeadership bisa sangat efektif ketika diterapkan pada karyawan milenial karena mereka sebagian besar ahli teknologi. Penerapan e-Leadership dapat mendukung proses kepemimpinan dalam organisasi dengan cara yang prosesnya lakukan secara virtual. Misalnya, pertemuan dan pelatihan rutin dilakukan melalui internet. Hal ini memungkinkan karyawan untuk memiliki jadwal dan pengaturan kerja yang lebih fleksibel karena mereka tidak harus datang ke kantor pada jam yang sama setiap hari dan mereka dapat melakukan pekerjaan dari rumah. Ini dapat mengarah pada 
keseimbangan kehidupan kerja yang lebih baik - nilai kerja yang penting bagi milenial (Ningky Sasanti Munir, 2020).

\section{REFERENSI}

Baihaqi, M. Fauzan. 2010. Pengaruh Gaya Kepemimpinan terhadap Kepuasan Kerja dan Kinerja dengan Komitmen Organisasi sebagai Variabel Intervening. Skripsi. Universitas Diponegoro. Jakarta

Colin J. Turey. 2013. Perceptions of Leadership Styles and Job Satisfaction in a Sample of High School Athletic Directors in the United States.University of North Florida.

David J. Weiss, Rene V. Dawis, George W. England, Lylod H. Lofquist. 1967. Manual for The Minnesota Satisfaction Questionnaire. Industrial Relations Center University of Minnesota.

EBSCO Corporate Solutions.2016. Millennials In The Workplace. Finding Information To Get The Job Done.

Najda Hayajneh, Taghrid Suifan, Bader Yousef Obeidat, Mohammd Abuhashesh, Raed Kareem Kanaan. 2020. The Relationship between Organizational Changes and Job Satisfaction in the Jordanian Telecommunication Industry. Journal of Social Sciences. Vol 9, Number 1.

Ningky Sasanti Munir. 2020. Kunci bagi Pemimpin Para Milenial. SWAOnline. Kelompok Keahlian Transformasi Stratejik dan Inovasi PPM Manajemen. 10 Maret.

Sugiyono. (2017). Metode Penelitian Kuantitatif, Kualitatif, dan R\&D. Bandung :Alfabeta, CV.

Syarif Hidayatullah, Abdul Waris *, Riezky Chris Devianti, Syafitrilliana Ratna Sari, Irawan Ardi Wibowo, Pande Made PW.2018. Perilaku Generasi Milenial dalam Menggunakan Aplikasi Go-Food. Jurnal Manajemen dan Kewirausahaan. Vol.6..No.2.hal.240-249.

Raden Andriani Lestari, 2014. Pengaruh Kepemimpinan Partisipatif Dan Komitmen Organisasi Terhadap Efektifitaslmplementasi Rencana Stratejik Pada Madrasah Aliyah Di Kabupaten Sukabumi Jawa Barat. Universitas Pendidikan Indonesia.

Rahmatika Sari Amalia dan Cholicul Hadi. 2019. Peran desain pekerjaan dan karir bagi karyawan generasi milenial. Jurnal Fenomena, Vol. 28 No. 1, hal. 10-21

Sulieman Ibraheem Shelash Mohammad, Hussein Ali AL-Zeaud, Ayat Mohammad Essam Batayneh2. 2011. The relationship between transformationalleadership and employees' satisfaction atJordanian private hospitals. Business and Economic Horizons. Vol 5. Issue2. 1. pp; 35-46.

Susilo Toto Raharjo, Durrotun Nafisah. 2006. Analisis Pengaruh Gaya Kepemimpinan TerhadapKepuasan Kerja, Komitmen OrganisasiDan Kinerja Karyawan(Studi Empiris Pada Departemen AgamaKabupaten Kendal DanDepartemen Agama Kota Semarang). Jurnal Studi Manajemen \& Organisasi. Vol. 3, No. 2. Hal 69.

Suyanto. 2018.2 Transformational Leadership :Gaya Kepemimpinan Millennial Di Era Industri 4.0.Working Papers of Innovation in Economics.

Uzair Khuwaja, Kaleem Ahmed, Ghulam Abid \& Ahmad Adeel. 2020. Leadership and employee attitudes: The mediating role of perception of organizational politics. Cogent Business \& Management. 7:1, 1720066. 